\title{
Makna Dan Fungsi Itikad Baik Dalam Kontrak Kerja Konstruksi
}

\author{
Barnabas Dumas Manery \\ Dosen Fakultas Hukum Universitas Pattimura \\ E-mail:manerydumas@yahoo.com
}

\begin{abstract}
Neither law nor doctrine can provide a clear understanding of good faith in contract law. In general, the study of good faith tends to mix up the notion of good faith as the rule of law in good faith as the principle of contract law. Based on this understanding, Article 1338 Paragraph (3) BW is considered as the legal principle of the contract so it concludes that the obligation of good faith exists only at the stage of contract implementation. Such opinion has obscured the meaning and function of good faith as the principle of contract law, which became the legal issue in this study. The approach used is (statute approach), (case approach), and (conceptual approach). Based on the results of the research, it is found that the essence of good faith is honesty and fairness which contains the meaning of trust, transparency, autonomy, obedience, without coercion and without deceit; as well as the function of the principle of good faith is to complement the legal system through the legislator and authorize through the authority of the judge in the form of adding, limiting and excluding a contractual obligation. Thus the law becomes flexible and able to guarantee complex and dynamic community legal needs.
\end{abstract}

Keywords: good faith, construction contract.

\section{A. PENDAHULUAN.}

Peningkatan dan perkembangan interaksi antarmanusia di dalam masyarakat baik dari kuantitas maupun kualitas berjalan seiring dengan perkembangan kebutuhan manusia dalam kehidupan modern yang semakin kompleks. Upaya pemenuhan kebutuhan manusia itu diwujudkan melalui berbagai interaksi antar manusia yang bersifat multidimensional; antara pengguna dan penyedia kebutuhan, antara penyedia kebutuhan dan industri dalam berbagai skala, antara industri penyedia barang atau jasa dengan pihak pengembang dan penghasil teknologi baik di bidang industri maupun komunikasi dan informasi, bahkan interaksi antar manusia dikaitkan dengan upaya mempertahankan kelestarian dan daya-dukung lingkungan hidupnya.

Upaya pemenuhan kebutuhan manusia yang diwujudkan dalam 
berbagai interaksi kemasyarakatan untuk sebagian besar dilaksanakan melalui kegiatan-kegiatan pertukaran barang dan jasa, baik untuk kepentingan komersial maupun person. Kegiatan-kegiatan pertukaran yang menimbulkan perikatan diwujudkan melalui pelaksanaan kewajiban kewajiban yang diterbitkan secara sukarela berdasarkan perjanjian maupun kewajiban-kewajiban yang terbit merupakan perintah hukum atau undang-undang. ${ }^{1}$

Di Indonesia perkembangan pertukaran barang dan jasa khususnya sektor jasa konstruksi sangat pesat dan cukup menggembirakan. Faktor penyebab tumbuh dan berkembangnya hukum kontrak adalah karena pengaruh globalisasi, pesatnya kegiatan bisnis yang dilakukan dalam masyarakat moderen dan pesatnya transaksi yang dilakukan oleh pemerintah dengan pihak lain. Pemerintah, baik pemerintah pusat maupun pemerintah daerah sebagai badan hukum publik, tidak hanya dapat melakukan perbuatan hukum yang bersifat publik, namun dapat juga melakukan suatu perbuatan hukum di bidang keperdataan. ${ }^{2}$

Salah satu perbuatan hukum pemerintah di bidang hukum privat adalah melaksanakan Kontrak Pengadaan Barang/Jasa Pemerintah khususnya Kontrak Kerja Konstruksi untuk memenuhi kebutuhan infrastruktur pelayanan publik. Ketentuan menyangkut hubungan kontraktual antara pemerintah dengan pihak swasta tidak diatur dalam BW sehingga termasuk dalam perjanjian tidak bernama (innominaat), yaitu perjanjian-perjanjian yang lahir berdasarkan asas kebebasan berkontrak Oleh sebab itu, Kontrak Kerja Konstruksi

\footnotetext{
1 Pasal 1233 BW, “Tiap-tiap perikatan dilahirkan baik karena persetujuan, baik karena undang-undang"

2 Salim, HS, Perkembangan Hukum Kontrak di luar Hukum Perdata, RajaGrafindo Persada, Jakarta 2008., h. 1.
}

antara pemerintah sebagai Pengguna Jasa dengan pihak swasta sebagai Penyedia Jasa konstruksi, berlaku aturan hukum kontrak pada umumnya dan berlaku juga ketentuan perundang-undangan yang terkait dengan Jasa Konstruksi.

Kontrak yang dibuat oleh pemerintah bersifat multi aspek dan mempunyai karakter yang khas. ${ }^{3}$ Sebagai konsekuensi pemanfaatan instrumen hukum perdata oleh pemerintah, khususnya Hukum Kontrak dalam pengelolaan urusan pemerintahan yang lazimnya disebut sebagai kontraktualisasi (contractualization), terjadi percampuran antara elemen privat dan publik dalam hubungan kontraktual yang terbentuk. ${ }^{4}$ Kontrak yang dibuat oleh pemerintah karenanya mempunyai karakteristik yang berbeda dengan kontrak privat pada umumnya. Adanya warna publik di dalam hukum kontrak ini merupakan ciri khas yang membedakan dengan kontrak komersial pada umumnya. Apabila dalam kontrak komersial para pihak mempunyai kebebasan yang sangat luas dalam mengatur hubungan hukum atau mengatur kewjiban-kewajiban kontraktual mereka, maka di dalam Kontrak Kerja Konstruksi kebebasan ini tidak sepenuhnya berlaku sebab terhadap kontrak ini berlaku ketentuan hukum publik yang sifatnya memaksa (dwingendrecht) yaitu undang-undang nomor 2 Tahun 2017 tentang Jasa Konstruksi (UU No.2/2017).

UU No. 2/2017 mengatur Kontrak Kerja Konstruksi pada tahapan

\footnotetext{
3 Charles Tiefer, et.al, Government Contract Law, Carolina Academic Press, North Carolina, 1999.,p.17.

4 H.Purwosusilo, Aspek Hukum Pengadaan Barang dan Jasa, Prenadamedia Group, Jakarta, 2014. h., 91; "keterlibatan pemerintah dalam hubungan kontraktual ini berbeda dengan kontrak komersial pada umumnya, karena karakteristik dari kontrak ini tidak murni lagi merupakan tindakan hukum privat, tetapi juga sudah ada campuran hukum publik di dalamnya".
} 
pembentukan kontrak atau prakontrak sedangkan pada tahapan pelaksanaan kontrak berlaku hukum kontrak menurut BW. Dengan demikian maka asas-asas hukum yang menjadi landasan Kontrak Kerja Konstruksi adalah asas-asas Jasa Konstruksi dan asas-asas hukum kontrak BW. Asas-asas Jasa Konstruksi sebagaimana diatur dalam UU No. 2/2017 adalah asas kejujuran dan keadilan, asas manfaat, asas kesetaraan, asas keserasian, asas keseimbangan, asas kemandirian, asas keterbukaan, asas kemitraan, asas keamanan dan keselamatan, asas kebebasan, asas pembangunan berkelanjutan, dan asas kelestarian lingkungan berlaku dalam tahapan prakontrak. ${ }^{5}$ Dalam tahapan pelaksanaan kontrak berlaku asas-asas hukum kontrak pada umumnya yaitu, asas kebebasan berkontrak, asas konsensualisme, asas pacta sunt servanda, dan asas kebebasan berkontrak.

Menurut Paul Scholten ${ }^{6}$, "asas hukum ialah pikiran-pikiran dasar yang terdapat di dalam dan dibelakang sistem hukum masing-masing dirumuskan dalam aturan-aturan perundang-undangan dan putusan-putusan hukum yang berkenaan dengan ketentuan-ketentuan dan keputusan-keputusan individual dapat dipandang sebagai penjabarannya”. J.J.H. Bruggink, ${ }^{7}$ menyatakan bahwa "asas hukum sebagai sejenis meta-kaidah berkenaan dengan kaidah perilaku ${ }^{8}$,

5 Asas Jasa Konstruksi menurut UU No. 18/1999 adalah asas kejujuran dan keadilan, asas manfaat, asas keserasian, asas keseimbangan, asas kemandirian, asas keterbukaan, asas kemitraan dan keselamatan demi kepentingan masyarakat, bangsa dan negara.

6 Paul Scholten di dalam JJ. H. Bruggink, Refleksi Tentang Hukum (alih bahasa oleh Arief Sidharta), Cipta Aditya Bakti, Bandung 1996, h., 119-120

7 Ibid.

8 Scholten menggunakan "aturan hukum" (rechtsregel) dengan istilah kaidah perilaku, J.J.H. Bruggink, Ibid, h. 125 . sementara itu asas hukum itu juga dapat memenuhi fungsi yang sama seperti kaidah perilaku. Sebab, meta-kaidah itu memuat ukuran atau kriteria nilai (waarderingsnormen). Fungsi asas hukum itu adalah merealisasikan ukuran nilai itu sebanyak mungkin dalam kaidah-kaidah dari hukum positif dan penerapannya".

Dalam praktek penyelenggaraan usaha Jasa Konstruksi, makna dan fungsi asas hukum kontrak khususnya asas itikad baik sebagai kaidah perilaku bagi para pihak masih menjadi salah satu isu penting sehingga memerlukan suatu kajian tersendiri. Maka berdasarakan latar belakang tersebut, penulis ingin mengkaji lebih lanjut tentang bagaimana makna dan fungsi asas itikad baik dalam kontrak konstruksi?

\section{B. PEMBAHASAN}

\section{Landasan Filosofi Kontrak Kerja Konstruksi}

Setiap aturan hukum atau norma mempunyai landasan filosofi. Agus Yudha Hernoko, ${ }^{9}$ Suatu aturan atau norma pada hakikatnya mempunyai dasar filosofi serta pijakan asas atau prinsip sebagai ruhnya. Principle menurut Black's Law Distionary adalah " $a$ fundamental truth or doctrine, as of law; a comprehensive rule of doctrine which furnishes a basis or origin for others" 10 yang esensi maknanya, asas adalah ajaran atau kebenaran yang mendasar untuk pembentukan aturan hukum yang

\footnotetext{
9 Agus Yudha Hernoko, Hukum Perjanjian, Asas Proporsionalitas dalam Kontrak Komersial, Prenadamedia Group, Jakarta 2014., h. 21.

10 Henry Campbell Black, Black's Law Dictionary, Definition of the Terms and Pharases of American and English Jurisprudence Anciet and Modern, West Publisihing Co, St. Paul Min, p. 828.
} 
menyeluruh. G.W. Paton ${ }^{11}$, Prinsip hukum merupakan dasar dari aturan hukum. Aturan hukum yang terbentuk memperoleh dasarnya dari prinsip hukum. Pendapat yang sama dikemukakan oleh Paul Scholten 12: "asas hukum ialah pikiran-pikiran dasar yang terdapat di dalam dan dibelakang sistem hukum masing-masing dirumuskan dalam aturan-aturan perundang-undangan dan putusan-putusan hukum yang berkenaan dengan ketentuan-ketentuan dan keputusan-keputusan individual dapat dipandang sebagai penjabarannya".

Berdasarkan defenisi Scholten, Bruggink menyimpulkan bahwa asas-asas hukum mewujudkan sejenis sistem sendiri, yang sebagian termasuk ke dalam sistem hukum, tetapi sebagian lainnya tetap berada di luarnya. Sementara itu asas hukum itu juga dapat memenuhi fungsi yang sama seperti kaidah perilaku. Sebab, meta-kaidah itu memuat ukuran/kriteria nilai (waarderingsnormen). Fungsi asas hukum itu adalah merealisasikan ukuran nilai itu sebanyak mungkin dalam kaidah-kaidah dari hukum positif dan penerapannya". Dalam hal ini pikiran Scholten terarah pada sistem hukum positif. Peranan ganda dari asas hukum berkenaan dengan sistem hukum positif itu berkaitan dengan sifat (karakter) khas asas hukum sebagai kaidah penilaian (waarderingsnormen).

Menurut Theo Huijbers, ${ }^{13}$ asas hukum ialah prinsip-prinsip yang dianggap dasar atau fundamen hukum. Asas-asas itu dapat disebut juga

11 G.W. Paton, A Text-book of Jurisprudence, Oxford University Press, Oxford, 1964, p. 204-205

12 Paul Scholten, Rechtsbeginselen, 1935, dalam Verzamelede Geschiften, jilid 1, 1949., h. 402. di dalam JJ. H. Bruggink, Op. Cit., hal. 119-120.

13 Theo Huijbers, Filsafat Hukum, Penerbit Kanisius, Yogyakarta 1995., h 81. pengertian-pengertian dan nilai yang menjadi titik tolak berpikir tentang hukum. Asas-asas itu merupakan titik tolak juga bagi pembentukan undang-undang dan interprestasi undang-undang tersebut. Van Eikema Hommes; ${ }^{14}$ "asas hukum itu tidak boleh dianggap sebagai norma-norma hukum yang konkrit, akan tetapi perlu dipandang sebagai dasar-dasar umum atau petunjuk-petunjuk bagi hukum yang berlaku. Pembentukan hukum praktis perlu berorientasi pada asas-asas hukum tersebut. Dengan kata lain asas hukum ialah dasar-dasar atau petunjuk arah dalam pembentukan hukum positif".

Dapat disimpulkan bahwa asas hukum adalah nilai/pikiran dasar sebagai landasan filosofi aturan hukum bersifat abstrak, umum dan dinamis berfungsi sebagai sumber aturan hukum yang dikonkritkan ke dalam sistem hukum melalui undang-undang dan keputusan hakim.

Mariam Darus Badrulzaman ${ }^{15}$, Asas-asas hukum kontrak yang tersirat dalam BW yaitu, Asas Kebebasan Berkontrak, Asas Mengikat Sebagai Undang undang, Asas Konsensualitas, dan Asas Itikad Baik. Asas-asas hukum kontrak ini berlaku bagi setiap kontrak atau perjanjian baik perjanjian bernama maupun perjanjian yang tidak bernama. Khususnya untuk kontrak yang melibatkan pemerintah dalam hal ini Kontrak Kerja Konstruksi, hubungan pengikatan para pihak bersumber pada aturan hukum publik dan juga bersumber pada aturan hukum privat. Aturan hukum publik berlaku pada tahan prakontrak adalah UU No. 2/2017 beserta ketentuan pelaksanaannya dan selanjutnya pada

14 Dalam Notohamidjojo, Soal-Soal Pokok Filsafat Hukum, BPK Gunung Mulia, Jakarta 1975., h. 49.

15 Mariam Darus Badrulzaman (buku 2), "KUHPerdata Buku III Hukum Perikatan Dengan Penjelasan”, Alumni Bandung 1993., hal.108. 
tahapan pelaksanaan kontrak berlaku hukum kontrak menurut BW. Dengan demikian, asas-asas hukum yang berlaku pada tahapan prakontrak adalah asas-asas hukum Jasa Konstruksi dan asas-asas hukum yang terkait dengan Jasa Konstruksi yaitu, prinsip-prinsip pengadaan barang/jasa pemerintah, asas-asas pengelolaan keuangan negara dan asas-asas pemerintahan yang baik dan pada tahapan pelaksanaan terintegrasi dan terpadu ${ }^{16}$ dalam asas-asas hukum kontrak pada umumnya.

\section{Itikad Baik Dalam Hukum Kontrak}

Undang-undang dan doktrin belum dapat memberikan batasan yang jelas menyangkut pengertian itikad baik, tetapi pada umumnya mengenal pembedaan sifat itikad baik yaitu sifat subjektif dan sifat objektif.

Wirjono Prodjodikoro, 17 menyebut itikad baik dengan istilah "kejujuran" dan membedakan dengan "kepatutan" selanjutnya menjelaskan bahwa kejujuran terdiri dari dua macam, yaitu;

1. Kejujuran pada waktu mulai berlakunya perhubungan hukum, seperti kejujuran memegang barang sebagai salah satu syarat guna

16 Mertokusomo (buku 2), Op. cit. h. 48, "Asas hukum tidak mengenal hierarki, artinya bahwa asas hukum tidak mengenal tingkatan-tingkatan: tidak ada asas hukum yang mempunyai kedudukan yang lebih tinggi dari asas hukum yang lain. Dengan demikian asas hukum tidak mengenal konflik satu sama lain. Walaupun berbeda atau bertentangan satu sama lain, keduanya dapat eksis secara berdampingan, tanpa mengalahkan atau meniadakan yang lain. Dua asas hukum yang berbeda atau bahkan bertentangan satu sama yang lain, keduanya tidak dapat dipisahkan tetapi membutuhkan satu sama lain merupakan suatu antinomi.

17 Lihat Wijono Prodjodikoro, Asas-asas Hukum Perjanjian, Mandar Maju Bandung 2011, h., 102-107. memperoleh milik barang yang dipegang itu secara lampau waktu "verjaring". Kejururan ini berupa pengiraan dalam hati sanubari seseorang bahwa syarat-syarat dimulainya hubungan hukum telah terpenuhi. Hukum memberikan perlindungan kepada pihak yang berperilaku jujur, sedangkan bagi pihak yang beritiked tidak baik (te kwade trouw) harus bertanggung-jawab dan menanggung risiko. Kejujuran dimaksud antara lain terkandung dalam Pasal 1963 dan Pasal 1977 BW yang menentukan syarat atas barang melalui daluwarsa, Kejujuran ini bersifat subjektif dan statis; dan

2. Kejujuran pada waktu pelaksanaan hak-hak dan kewajiban-kewajiban dalam suatu hubungan hukum. Pasal 1338 ayat (3) BW kejujuran dalam pelaksanaan perjanjian terletak pada keadaan jiwa manusia yang titik berat terletak pada tindakan kedua belah pihak dalam melaksanakan janji. Hal kejujuran adalah hal yang selalu bersifat subjektif, dan yang bersifat objektif adalah yang berkaitan dengan kepatuhan (billikheiid, redelijkheid). Kepatutan yang mempunyai sifat objektif, terletak terutama pada keadaan sekitar persetujuan. Syarat kepatutan (billikheiid, redelijkheid) ini sebetulnya berakar pada suatu sifat peraturan pada umumnya, yaitu usaha untuk mendapatkan keseimbangan dari berbagai kepentingan yang ada di masyarakat. Dalam suatu tata hukum pada hakekatnya tidak diperbolehkan kepentingan seseorang dipenuhi seluruhnya dengan akibat kepentingan orang lain sama sekali didesak atau diabaikan.

Subekti $^{18}$, mengartikan itikad baik dengan "jujur", "kejujuran" Pasal 1338 ayat (3) BW, semua perjanjian itu harus

18 Subekti, Hukum Prejanjian, Intermasa, Jakarta 1996. h., 41. 
dilaksanakan dengan itikat baik (dalam bahasa Belanda tegoeder trouw; dalam bahasa Inggris in good faith, dalam bahasa Prancis de bonne foi). Norma ini merupakan salah satu sendi yang terpenting dari Hukum Perjanjian. Selanlutnya membedakan ke dalam dua anasir yaitu anasir subjektif dan anasir objektif, sebagai berikut:

1. Anasir subjektif terdapat dalam Hukum Benda misalnya, ada perkataan-perkataan pemegang barang yang beritikad baik, pembeli barangyang beritikat baik dan lain sebagainya sebagai lawan dari orang orang yang beritiked buruk. Seorang pembeli barang yang beritiked baik, adalah orang yang membeli barang dengan penuh kepercayaan bahwa ia si penjual sungguh-sungguh pemilik sendiri dari barang yang dibelinya itu. Ia sama sekali tidak mengetahui bahwa ia membeli barang dari bukan pemilik, dianggap sebagai pembeli yang jujur. Dalam Hukum Benda, itikad baik yang berarti kejujuran atau bersih. Si pembeli yang beritikad baik adalah orang yang jujur, orang yang bersih. Ia tidak mengetahui tentang adanya cacat-cacat yang melekat pada barang yang dibelinya. Artinya cacat mengenai asal-usulnya. Bukan itikad baik inilah yang dimaksudkan oleh Pasal 1338 ayat (3) bahwa semua perjanjian harus dilaksanakan dengan itikad baik; dan

2. Anasir objektif, terdapat dalam Pasal 1338 ayat (3) BW yaitu pelaksanaan itu harus berjalan dengan mengindahkan norma-norma kepatutan dan kesusilaan. Jadi ukuran-ukuran objektif menilai pelaksanaan tadi. "pelaksanaan perjanjian harus berjalan di atas rel yang benar". Pasal 1339 BW memberikan kekuasaan pada hakim untuk mengawasi pelaksanaan suatu perjanjian agar jangan sampai pelaksanaan itu melanggar kepatutan atau keadilan. Ini berarti, hakim itu berkuasa untuk menyimpang dari isi perjanjian menurut hurufnya, manakala pelaksanaan menurut huruf itu akan bertentangan dengan itikad baik. Tujuan hukum selalu mengejar dua tujuan yakni menjamin kepastian (ketertiban) dan memenuhi tuntutan keadilan. Kepastian hukum menghendaki supaya apa yang dijanjikan harus dipenuhi (ditepati). Namun, dalam menuntut dipenuhinya janji itu, janganlah orang meninggalkan norma-norma keadilan atau kepatutan.

Berdasarkan pendapat Wirjono Prodjodikoro dan Subekti dapat disimpulkan bahwa itikad baik dapat dibedakan atas itikad baik yang bersifat subjektif dan itikad baik yang bersifat objektif. Itikad baik yang bersifat subjektif hakikatnya adalah kejujuran berlaku pada tahapan prakontrak sedangkan itikad baik yang bersifat objektif hakikatnya adalah kepatutan/keadilan yang berlaku pada tahapan pelaksanaan kontrak.

\section{Itikad Baik Sebagai Aturan Hukum Dan Itikad Baik Sebagai Asas Hukum}

Kajian tentang itikad baik dapat kita temukan di dalam berbagai literatur hukum. Walaupun demikian sampai sekarang belum ada undang-undang mapun doktrin yang memberikan batasan yang jelas menyangkut pengertian itikad baik sebagai norma/aturan hukum dan hubungannya dengan itikad baik sebagai asas hukum. Dari hasil penelitian ditemukan bahwa terdapat kecenderungan kajian mencampur adukan pengertian itikad baik sebagai aturan hukum dan itikad baik sebagai asas hukum. Sebagai contoh pembahasan itikad baik yang terdapat dalam Pasal 1338 ayat (3) BW diartikan sebagai asas hukum kontrak sehingga melahirkan kesimpulan itikad baik hanya ada dalam pelaksanaan kontrak. Dengan perkataan lain, sampai sekarang belum ada doktrin yang menguraikan secara 
tegas pembedaan makna dan fungsi itikad baik sebagai aturan hukum dan itikad baik sebagai asas hukum kontrak. Pemahaman itikad baik sebagai aturan hukum dan itikad baik sebagai asas hukum kontrak sangat penting untuk menjawab perbedaan pendapat terkait dengan kewajiban itikad baik pada tahapan prakontrak.

Hubungan antara aturan dan asas sifatnya problematis, Ada pendapat melakukan pembedaan secara gradual, misalnya pembedaan antara keduanya dicari dalam karakter asas-asas hukum yang cenderung lebih abstrak ketimbang aturan. Dworkin 19 mengajukan dua kriteria pembeda yaitu, pertama yang terpenting ialah derajat konretisasi dan kedua adalah berkenaan dengan persoalan apakah dengan aturan-aturan yang ada berlaku atau tidak berlaku; aturan-aturan yang ada tersebut niscaya memiliki karakter berlaku atau tidak, sedemikian sehingga tidak ada tempat untuk menimbang-nimbang jalan tengah. ${ }^{20}$

Dalam hal aturan-aturan hukum yang ada tidak dapat menetapkan apa hukumnya atau memecahkan persoalan akan dibutuhkan bantuan asas-asas hukum untuk memberikan makna terhadap aturan-aturan hukum yang telah ada. Setiap kasus (hukum) harus dipecahkan dan ini berarti pula setiap kali kita akan memerlukan penafsiran sebagai semacam pelengkap. ${ }^{21}$ Menurut Leijte, Asas hukum haruslah "diperjuangkan bukan pada tataran penilaian rasio manusia, melainkan pada tataran kesusilaan. Asas hukum tidak sekadar

19 R.Dworkin (buku 1), Taking Richts Seriously, Harvard University Press, Cambrigde, Massachcussetts, 1977, h. 24, dalam Herlina Budiono, Ibid, h.77.

20 R.Dworkin (buku 2), Low"s Empire, Fontana Press, Herper Collins Publishers, London, 1991, h. 50, dalam Herlina Budiono, Ibid, h. 77.

21 R. Dworkin (buku 1), Loc. Cit., h. 24, dalam Herlina Budiono, Ibid, h. 80. bersifat umum, melainkan juga bersifat terberi dan niscaya. Bila tidak demikian halnya, maka hilanglah karakternya sebagai asas". ${ }^{22}$ Fungsi asas hukum menurut Klanderman bersifat mengesahkan dan mempunyai pengaruh yang normatif dan mengikat para pihak. Bersifat mengesahkan karena mendasarkan eksistensinya pada rumusan oleh pembentuk undang-undang dan hakim. Akan tetapi disamping itu fungsi asas hukum dalam hukum adalah melengkapi sistem hukum: membuat sistem hukum luwes. Dalam hal kita mempelajari ilmu hukum asas hukum mempermudah dengan memberi ikhtiar. ${ }^{23}$

K.J. Kraan, ${ }^{24}$ bahwa; “ terjadinya hukum berlangsung melalui pikiran yang bersifat abstrak, umum dan mendasar yang disebut asas hukum dan kemudian dikonkretisasi lebih lanjut menjadi peraturan hukum konkret. Jadi hukum direalisasikan dalam empat tahap; asas hukum, kaidah hukum, peraturan hukum konkret dan yurisprudensi. Meskipun asas hukum dikonkretisasi menjadi peraturan hukum konkret tetapi tidak terjerumus dan larut dalam konkretisasi itu, melainkan mempertahankan "nilai tambah" dengan selalu ada dalam situasi baru yang tidak terduga tetapi dapat diharapkan. Dengan demikian, asas hukum merupakan unsur kreatif dan dinamis yang penting dalam tata hukum". Berdasarkan pendapat Kraan, Sudikno Metrokusumo $^{25}$ menyimpulkan bahwa;

22 J.C.M. Leijten, Beginsel en Tegenbeginsel in het Recht, AA 40 (1991) 10 (725), h.9., dalam dalam Herlina Budiono, Ibid, h. 81.

23 Mertokusumo, (buku 1), Penemuan Hukum, Sebuah Pengantar, Liberty, Yogyakarta 2004..h., 6.

24 K.J. Kraan, Sylabus Rechtssysteem, Universiteit van Amsterdam, 1981. h. 28. Dalam Sudikno Metrokusumo (buku 2), Teori Hukum, Edisi Revisi, Cahaya Atma Pustaka, Yogyakarta, 2012. h. 45-46.

25 Sudikno Metrokusumo (buku 2), Ibid., h.46. 
"asas hukum merupakan pikiran dasar yang bersifat umum yang mendasari atau yang terdapat di dalam atau di belakang peraturan hukum konkret. Dengan kata lain, asas hukum tersirat di dalam peraturan hukum konkret seperti misalnya asas kelayakan, asas Itikad baik, walaupun tidak tertutup kemungkinan ada asas hukum yang tersurat atau dituangkan di dalam peraturan hukum konkret, seperti asas nulum delictum nulla poena sine praevia legi poenale (Pasal 1 ayat (1) KUHP) dan presumption of innocence (Pasal 8 UU No. 4 Th 2004)". Nieuwenhuis ${ }^{26}$ menjelaskan hubungan fungsional antara asas dan ketentuan hukum (rechtsgels) sebagai berikut:

1. Asas-asas hukum berfungsi sebagai pembangun sistem. Asas-asas itu tidak hanya mempengaruhi hukum positif, tetapi juga dalam banyak hak menciptakan suatu sistem. Suatu sistem tidak akan ada tanpa adanya asas-asas;

2. Asas-asas itu membentuk satu dengan lainnya suatu sistem check and balance. Asas-asas ini sering menunjuk ke arah yang berlawanan, apa yang kiranya menjadi merupakan rintangan ketentuan-ketentuan hukum. Oleh karena menunjuk ke arah yang berlawanan, maka asas-asas itu saling kekang mengekang, sehingga ada keseimbangan.

Pemahaman bahwa itikad baik dalam pasal Pasal 1338 ayat (3) BW adalah asas hukum kontrak tidak tepat. Itikad baik yang tersurat dalam Pasal 1338 ayat (3) BW adalah aturan hukum konkret. ${ }^{27}$ Itikad baik dalam hukum

26 Henry P. Panggabean, Penyalahgunaan Keadaan, (Misbruik van Omstandigheden) sebagai Alasan (Baru) untuk Pembatalan Perjanjian (Berbagai Perkembangan Hukum di Belanda), Liberty, Yogyakarta, 1999., h 7.

27 Sudikno Mertokusumo, (buku 2), Op. cit., h. 46 ,menyatakan “ ... asas hukum yang tersirat di dalam peraturan hukum konkret, seperti misalnya asas kelayakan, asas Itikad baik, walaupun tidak tertutup kemungkinan ada asas kontrak hendaknya dapat dibedakan atas; itikad baik sebagai aturan hukum kontrak dan itikad baik sebagai asas hukum kontrak. Sebagai aturan hukum konkret termasuk dalam tataran dogmatik hukum, sedangkan sebagai asas hukum termasuk dalam tataran filsafat hukum. Dengan demikian itikad baik sebagai aturan hukum konkret jika ditafsirkan secara gramatikal $^{28}$ mengandung makna hanya ada pada tahap pelaksanaan kontrak. Berbeda dengan itikad baik dimaknai sebagai asas hukum kontrak yang wilayah penerapannya tidak terbatas pada pelaksanaan kontrak tetapi pada semua tahapan kontrak, yaitu tahapan prakontrak, pelaksanaan kontrak dan penyelesaian sengketa. ${ }^{29}$

Itikad baik sebagai asas hukum kontrak hakikatnya adalah kejujuran dan kepatutan/keadilan yang mengandung makna kepercayaan, transparansi, otonom, taat norma, tanpa paksaan dan tanpa tipu daya. Kejujuran dikonktretkan ke dalam aturan hukum positif antara lain adalah; Pasal 530, 531, 533 dan 548 BW tentang beziter yang beritikad baik, Pasal 1963; 1966 dan 1977 BW tentang kepemilikan terkait dengan kadaluawarsa; Pasal 1320 BW khususnya persyaratan kata sepakat dan suatu causa yang halal. Kepatutan/keadilan dikonkritkan dikonkritkan ke dalam aturan hukum Pasal 1321, 1323, 1328 BW tentang kehilafan, paksaan dan penipuan dalam pembuatan kontrak; Pasal 1348 BW tentang pembayaran dengan beritikad

hukum yang tersurat atau dituangkan di dalam peraturan hukum konkret."

28 Sudikno Mertokusumo (buku 3), Bab-Bab Tentang Penemuan Hukum, PT. Citra Aditya Bakti, Jakarta 1993., h 59; penafsiran gramatikal adalah mencoba menangkap arti suatu naskah menurut bunyi kata-katanya.

29 UU No. 2/2017 menetapkan tahapan prakontrak, tahapan pelaksanaan kontrak dan penyelesaian sengketa berada di dalam suatu sistem hukum kontrak. 
baik, Pasal 1337 BW tentang causa yang terlarang dan 1338, $1339 \mathrm{BW}$.

Itikad baik sebagai asas hukum kontrak, memiliki tiga fungsi dalam pelaksanaan kontrak: (1) Itikad baik berfungsi melengkapi/menambah (aanvullende werking van de goede trouw) isi perjanjian; (2) Itikad baik berfungsi membatasi pelaksanaan perjanjian (derogorende werking van de goede trouw); dan (3) Itikad baik berfungsi menghapuskan pelaksanaan perjanjian. ${ }^{30}$ Itikad baik sebagai asas hukum merupakan unsur naturalia dalam kontrak yaitu termasuk dalam sifat bawaan dari kontrak (natuur) sehingga secara diam-diam melekat pada kontrak. Fungsinya melengkapi kontrak dalam wujud mengisi kekosongan hukum, melengkapi/menambah dan meniadakan isi kontrak. Namun demikian fungsi melengkapi/menambah dan meniadakan menjadi kewenangan hakim dalam memutuskan perkara. Hakim mengkonkretisasi asas hukum itikad baik dalam bentuk putusan hakim. Berdasarkan pemahaman ini, maka dapat disimpulkan bahwa asas itikad baik bukan merupakan sumber hukum tetapi merupakan sumber dari aturan hukum.

\section{Makna Dan Fungsi Asas Itikad Baik Dalam Kontrak Kerja Konstruksi}

Pengertian Kontrak Kerja Konstruksi perlu dibedakan dengan pengertian dari kontrak pada umumnya. Jika dalam hukum kontrak pada umumnya sumber perikatan adalah perjanjian atau undang-undang, maka dalam Kontrak Kerja Konstruksi sumber perikatan adalah perjanjian dan undang-undang. Sebagai sebuah kontrak. Maka dalam proses pembuatannya harus melalui tahapan, karena dalam penulisan ini penulis akan menguraikan makna asa

30 Ridwan Khairandy, Itikad Baik Dalam Kebebasan Berkontrak, Program Pascasarjana Universirtas Indonesia, Jakarta, 2003. h. 261. itikad baik dalam tahap-tahapan kontrak tersebut.

a. Asas Itikad Baik dalam Tahapan Prakontrak

Pada tahap pra-kontraktual para pihak yang akan mengikatkan diri dalam kontrak pada umumnya melakukan proses tawar menawar (bargaining process). Salah satu pihak memberikan penawaran (offer) sedang pihak yang lain akan memberikan akseptasi manakala la menerima syarat-syarat yang diajukan oleh pihak pertama. Lazim juga proses ini disebut sebagai proses negosiasi untuk menuju terciptanya kata sepakat (mutual consent). Syarat ini merupakan yang terutama dalam hukum kontrak. Penawaran mengandung makna usulan untuk membuat kontrak ${ }^{31}$. Di dalamnya terkandung unsur esensialia kontrak yang hendak ditutup. Pihak yang ditawari (offeree) dengan penawaran ini memperoleh hak kehendak (wijsrecht) yaitu hak untuk menerima atau menolak penawaran itu.

UU No. 2/2017 antara lain menetapkan asas-asas Jasa Konstruksi adalah asas kejujuran dan keadilan, asas keterbukaan, asas kemitraan dan kesetaraan sama dengan prinsip transparansi, prinsip kompetitif dan prinsip responsiveness, dan prinsip-prinsip pengadaan baerang/jasa pemerintah yang berlaku pada tahapan prakontrak. Menurut Perpres No. 54/2010, sebelum terjadi kesepakatan antara pengguna dengan penyedia barang/jasa pemerintah terdapat tahap pemilihan penyedia barang/jasa. Tahapan pemilihan penyedia barang/jasa ini merupakan tahap menuju terciptanya kontrak bagi kedua belah pihak. Dalam kaitan ini prinsip transparansi berikut prinsip kompetitif

\footnotetext{
31 J.H. Niewenhuis, Poofdstukken Verbintenissenrecht, (Pokok-Pokok Hukum Perikatan) terjemahan D. Saragih, Universitas Airlangga, Surabaya 1985.h.,2.
} 
dan responsiveness merupakan prinsip utama yang harus diterapkan untuk mencapai tujuan pengadaan tidak saja sepadan dengan besarnya uang yang dibelanjakan tetapi juga dari segi kualitas dipertanggung-jawabkan. ${ }^{32}$ dapat

Dalam tahapan ini hakikat itikad baik adalah kejujuran yang mengandung makna para pihak yaitu Pengguna Jasa berkewajiban untuk menjelaskan fakta material sedangkan Penyedia Jasa berkewajiban untuk meneliti fakta material sebelum menandatangani kontrak.

b. Asas Itikad Baik dalam Tahapan Pelaksanaan Kontrak

Pelaksanaan kontrak merupakan pelaksanaan hak dan kewajiban para pihak sesuai dengan klausula yang telah disepakati dalam kontrak. Fungsi itikad baik dalam tahap ini terutama menyangkut fungsi membatasi, meniadakan dan menambah kewajiban kontraktual. Fungsi ini tidak boleh dijalankan begitu saja, melainkan hanya apabila terdapat alasan yang amat penting berdasarkan kewenangan hakim. Pembatasan itu hanya dapat dilakukan apabila suatu klausula tidak dapat diterima karena tidak adil.

Fungsi Itikad Baik dalam membatasi kewajiban kontraktual dapat dijumpai dalam putusan Mahkamah Agung R.I. No. 983.1/Pdt/1991, tanggal 26 September 1996 dalam perkara antara Haryo vs. Bank Pasar Dwimanda. Dalam perkara ini Haryo selaku debitur berada dalam keadaan wanprestasi dan dihukum untuk membayar hutangnya kepada kreditur tetapi hakim menurunkan tingkat bunga yang sebelumnya telah disepakati oleh para pihak; bunga yang tadinya $3.3 \%$ per bulan (39,6\% per tahun) menjadi $15 \%$ per

32 Yohanes. Sogar Simamora, Hukum Perjanjian, Prinsip Hukum Kontrak Pengadaan Barang dan Jasa oleh Pemerintah, Kantor Hukum "Wins \& Partners" bekerjasama dengan Laksbang Justitia Surabaya, 2012, hal., 165. tahun. Fungsi asas Itikad baik dalam membatasi kewajiban kontraktual dibidang kontrak konstruksi dapat dilihat dalam Putusan PN Ketapang, No. 17/Pdt.G/2012/PN.KTP tertanggal 18 Februari 2013. ${ }^{33}$ antara H.A. Babib Azan direktur CV. Irhan sebagai Penggugat melawan Pemerintah RI, cq. Menteri Dalam Negeri, cq. Gubernur Provinsi Kalimantan Barat, cq. Bupati Kabupaten Ketapang, cq. Dinas Pekerjaan Umum Kabupaten Ketapang, sebagai Tergugat I, dan Ketua DPRD Ketapang cq. Badan Anggaran sebagai Tergugat II. Pertimbangan hukum PN Ketapang bahwa, Tidak melaksanakan kewajiban kontraktual dengan alasan Keppres No. 80 Tahun 2003 yang melarang Pengguna Jasa melakukan ikatan perjanjian dengan Penyedia barang/jasa apabila belum tersedia anggaran adalah dalil yang tidak beralasan secara hukum dan alasan tersebut dapat mengurangi rasa kepercayaan dunia usaha kepada pemerintah in casu Pemerintah Daerah Ketapang. Bahwa seandainya pekerjaan tersebut belum ada anggaran seharusnya Tergugat I tidak membuat perjanjian dan memerintahkan Penggugat untuk mengerjakan pekerjaan. Dalam perkara ini Pengadilan menasfirkan itikad baik dengan kepatutan/ keadilan yaitu membatasi berlakunya Keppres No. 80 Tahun 2003 yang bersifat memaksa, karena dapat menimbulkan ketidak adilan.

Fungsi Itikad Baik dalam meniadakan kewajiban kontraktual dalam putusan Pengadilan Tinggi Medan; Nomor : 41/PDT/2015/PT-MDN, Tanggal 12 Maret $2015^{34}$ Anatara Lusianus Hadia Zokho Sarumaha; CV. Setia Karya sebagai Penggugat melawan Walikota Gunung Sitoli $\mathrm{Cq}$ Pejabat

33

https://putusan.mahkamahagung.go.id/.../pn-ke ta pang/.../wanpresta..

34 https://putusan.mahkamahagung.go.id/.../ptmedan/.../perbuatan-m. 
Pembuat Komitmen (PPK) Dinas Tata Ruang Perumahan dan Kebersihan Kota Gunungsitoli, sebagai Tergugat. Putusan Pengadilan Negeri Gunung Sitoli kemudian dikuatkan oleh Pengadilan Tinggi Medan menolak gugatan/banding Penggugat CV. Setia Karya dengan pertimbangan hukum; Bahwa Berita Acara Prestasi Kemajuan Kerja yang memuat pernyataan bahwa pekerjaan yang dilakukan oleh Penggugat telah mencapai persentasi sebesar $100 \%$ (seratus persen) semata-mata untuk membantu penyedia jasa dalam hal ini Penggugat untuk segera meneruskan penyelesaian pekerjaan tersebut hingga selesai dan bukan untuk mengklaim dana. ${ }^{35}$ Dalam perkara ini hakim menafsirkan Itikad Baik dengan kepatutan/keadilan dengan meniadakan kewajiban

kontraktual

Tergugat/Terbanding untuk memenuhi prestasinya dari suatu perikatan dengan causa itikad buruk (te kwade trouw). Pendapat pengadilan sejalan dengan Prinsip UNIDROIT, yaitu prinsip itikad baik (good faith) dan transaksi jujur (fair dealing) dan prinsip larangan bernegosiasi dengan itikad buruk.

Fungsi Itikad Baik dalam menambah kewajiban kontraktual, Putusan MA No.1574 K/Pdt/2011, tanggal 27 Februari $2012^{36}$ dalam perkara antara Pemerintah Kota Bekasi Pemohon kasasi dahulu Tergugat/Pembanding melawan PT. Helga Prima General Contractor Termohon kasasi dahulu Penggugat/Terbanding. Putusan Pengadilan Negeri Bekasi dikuatkan oleh Pengadilan Tinggi Bandung dan Mahkamah Agung menyatakan bahwa Tergugat Pemerintah Kota Bekasi telah melakukan perbuatan ingkat janji (wanprestasi) kepada Penggugat, dan

35 Kebijakan PPK (Tergugat) ini merupakan kebijakan yang salah dan bertentangan dengan undang-undang.

36 https://putusan.mahkamahagung.go.id/putusan /downloadpdf/.../pdf menghukum Tergugat untuk membayar kerugian biaya yang telah dikeluarkan Penggugat kepada Penggugat. Pertimbangan hukum Pengadilan bahwa, (1) pekerjaan pematangan lahan Rusunawa tahap pertama dan tahap kedua adalah satu paket sehingga perjanjian tahap pertama masih berlaku diantara para pihak yang berarti Penggugat dan Tergugat secara diam-diam melanjutkan perjanjian sebagaimana pelaksanaan pematangan tahap pertama; dan (2) proyek pematangan lahan yang dikerjakan oleh Penggugat adalah milik dari Tergugat menimbulkan hubungan hukum antara Penggugat dan Tergugat dan sepanjang perbuatan tersebut untuk dan atas nama Tergugat maka yang mempunyai tanggungjawab adalah Tergugat.

Pendapat pengadilan dalam perkara ini menafsirkan itikad baik sebagai kepatutan dan keadilan mengeyampingkan mekanisme dan tata-cara yang diatur dalam Keppres No. 80 Tahun 2003 dan lebih mempertimbangkan itikad baik dari Penggugat dalam menambah kewajiban kontraktual untuk melanjutkan pekerjaan pematangan lahan tahap kedua menjadi lahan Rusunawa yang siap bangun sehingga paket proyek pembangunan Rusunawa tidak dialihkan ke daerah lain.

\section{Asas Itikad Baik dalam Penyelesaian Sengketa}

Sektor konstruksi bersifat dinamis dan berbeda dengan kontrak di sektor lain. Faktor yang membedakan antara lain durasi proyek yang relatif panjang, kompleks, ukuran dan harga yang disepakati, serta jumlah pekerjaan dapat berubah setiap saat selama masa kontrak pelaksanaan konstruksi. Faktor-faktor tersebut menyebabkan kontrak konstruksi rawan sengketa. Jika sengketa tidak dapat diselesaikan secara baik, maka dampaknya adalah tertundanya pekerjaan konstruksi dan bahkan dapat terjadi terhentinya pekerjaan konstruksi secara 
total serta tidak terserapnya anggaran yang dialokasikan.

Antisipasi berbagai dampak kerugian bagi para pihak, terutama kerugian keuangan negara sebagai akibat dari perselisihan yang berkepanjangan, UU No 2/2017 memberikan kewajiban kepada para pihak untuk menentukan cara penyelesaian sengketa sebagai salah satu klausul dalam kontrak kerja konstruksi. Dengan demikian maka cara penyelesaian sengketa yang dipilih para pihak merupakan suatu kewajiban kontraktual dalam sistem hukum Kontrak Kerja Konstruksi. Sebagai konsekuensinya adalah berlaku ketentuan-ketentuan hukum kontrak dan asas-asas hukum kontrak dalam proses penyelesaian sengketa Kontrak Kerja Konstruksi. Oleh sebab itu Peraturan Pemerintah yang akan mengatur penyelesaian sengketa diharapkan dapat menjadikan asas-asas hukum kontrak sebagai sumber aturan hukum.

\section{PE N U T U P}

Kontrak Kerja Konstruksi yang diatur dalam UU No. 2/2017 memiliki landasan filosofi pada asas-asas jasa konstruksi yang dalam penyelenggaraannya terintergasi dengan asas kebebasan berkontrak, asas konsensualis, asas pacta sunt servanda dan asas itikad baik sebagai landasan yang menghidupkan berlakunya asas-asas hukum kontrak.

Hakikat asas itikad baik adalah kejujuran dan kepatutan/keadilan yang mengundung makna kepercayaan, transparansi, otonom, ketaatan, tanpa paksaan dan tanpa tipu daya. Hakikat asas itikad baik bersifat parmanen dan tidak berubah sedangkan makna itikad baik sifatnya dinamis dan senantiasa berubah menyesuaikan dengan kesadaran hukum masyarakat yang kompleks dan dinamis. Fungsi asas itikad baik dalam Kontrak Kerja Konstruksi adalah sebagai sumber aturan hukum. Oleh sebab itu dalam penyelesaian sengketa kontrak perlu ditafsirkan dengan itikad baik dan tidak semata-mata didasarkan kepada apa yang secara jelas diperjanjikan olah para pihak. Dengan demikian hakim dapat melaksanakan kewenangannya dalam menambah, membatsi dan meniadakan kewajiban kontraktual sehingga mampu menjamin kebutuhan hukum yang kompleks dan dinamis.

\section{DAFTAR PUSTAKA}

Anomin, Tindak Pidana Korupsi dalam Pengadaan Barang/Jasa Pemerintah, Kejaksaan Agung RI Jakarta, 2007

Badrulzaman, Mariam Darus (buku 2), "KUHPerdata Buku III Hukum Perikatan Dengan Penjelasan", Alumni Bandung 1993.

Campbell, Henry, Black's Law Dictionary, Definition of the

Terms and Pharases of American and English Jurisprudence Anciet and Modern, West Publisihing Co, St. Paul Min.

Dworkin, R. , Taking Richts Seriously, Harvard University Press, Cambrigde, Massachcussetts, 1977

---------, Low”s Empire, Fontana Press, Herper Collins Publishers, London, 1991,

Hernoko, Agus Yudha, Hukum Perjanjian, Asas Proporsionalitas dalam Kontrak Komersial, Prenadamedia Group, Jakarta 2014.

Huijbers, Theo, Filsafat Hukum, Penerbit Kanisius, Yogyakarta 1995.

Khairandy, Ridwan, Itikad Baik Dalam Kebebasan Berkontrak,Program 
Pascasarjana Universirtas

Indonesia, Jakarta, 2003.

K.J. Kraan, Sylabus Rechtssysteem,

Universiteit van Amsterdam, 1981.

Mertokusumo, Sudikno, Penemuan Hukum, Sebuah

Pengantar, Liberty, Yogyakarta 2004.

--------------, Teori Hukum, Edisi Revisi, Cahaya Atma Pustaka, Yogyakarta, 2012.

$B a b-B a b \quad$ Tentang

Penemuan Hukum, PT. Citra

Aditya Bakti, Jakarta 1993.

Mohammad Amari dan H. Asep M. Mulyana, Kontrak Kerja Konstruksi Dalam Perspektif Tindak Pidana, Penerbit Aneka Ilmu, Semarang 2010.

Notohamidjojo, Soal-Soal Pokok Filsafat Hukum, BPK Gunung Mulia, Jakarta 1975.

Leijten, J.C.M, Beginsel en Tegenbeginsel in het Recht, AA 40 (1991) 10 (725).

Panggabean, Henry P., Penyalahgunaan Keadaan, (Misbruik van Omstandigheden) sebagai Alasan (Baru) untuk Pembatalan Perjanjian (Berbagai Perkembangan Hukum di Belanda), Liberty, Yogyakarta, 1999.

Paton, G.W, A Text-book of Jurisprudence, Oxford University Press, Oxford, 1964.

Purwosusilo,H, Aspek Hukum Pengadaan Barang dan Jasa, Prenadamedia Group, Jakarta, 2014.

Prodjodikoro, Wijono, Asas-asas Hukum Perjanjian, Mandar Maju Bandung 2011.

Salim, HS, Perkembangan Hukum Kontrak di luar Hukum
Perdata, RajaGrafindo Persada, Jakarta 2008.

Subekti , Hukum Prejanjian, Intermasa , Jakarta 1996.

Simamora, Yohanes Sogar,(buku 1), Hukum Perjanjian, Prinsip Hukum Kontrak Pengadaan Barang dan Jasa oleh Pemerintah, Kantor Hukum "Wins \& Partners" bekerjasama dengan Laksbang Justitia Surabaya, 2012

Tiefer, Charles et.al, Government Contract Law, Carolina Academic Press, North Carolina, 1999.

\section{Websites}

https://putusan.mahkamahagung.go.id/.../ pn-ketapang/.../wanpresta..

https://putusan.mahkamahagung.go.id/.../ pt-medan/.../perbuatan-m.

https://putusan.mahkamahagung.go.id/put usan/downloadpdf/.../pdf 